\title{
Management of Dadru Kushta (Tinea corporis) through Ayurveda-A Case Study
}

\author{
Case Report
}

\section{Manish Hirasingh Chavhan ${ }^{*}$, Sadhana Misar Wajpeyi²}

1. Post Graduate Scholar, 2. Head of Department, Department of Kayachikitsa, Mahatma Gandhi Ayurveda College, Hospital, Research Centre, Salod (H), Wardha, Maharashtra.

\begin{abstract}
Skin is the largest organ of human body. Its size and external location makes it susceptible to various disorders. Skin diseases are mostly caused by infections like bacteria, fungi etc. All the skin diseases in Ayurveda have been classified under the broad heading of 'Kushta' which are further classified into Mahakushta and Kshudrakushta. Dadru is one amongst them. It is Raktapradoshaja vyadhi having kapha, pitta dominance. Due to similarity of all symptoms Dadru can be very well correlated with Tinea corporis which is a fungal infection especially caused due to poor hygienic conditions. In Ayurveda Shodhan and Shaman chikitsa is mainly indicated in Kushtha. A 50 yrs old female came with complaints of round and reddish patches over abdominal region with severe itching for 20 days. She was treated with Arogyavardhini vati, Gandhak rasayan, Gomutra siddha haritaki internally and Karanj oil and S-kin powder externally for 14 days. After completion of treatment, significant improvement was observed in the parameters like Kandu (itching), Raaga (Erythema), Pidika (eruptions) and Utsaana mandala (elevated circular skin lesion). In Samhita repeated shodhana is indicated in Kushtha hence nityavirechana in the form of Gomutra siddha haritaki was given. Arogyavardhini vati, Gandhak rasayan, Karanj oil and S-kin powder having Kushtaghna, Kandughana and Krumighna properties help in elimination of aggravated doshaja thus breaks the samprapti of the vyadhi. From this case study it can be concluded that Ayurvedic formulations are effective in the management of Dadru kushta.
\end{abstract}

Key Words: Kushta, Kandughna, Kushtaghna, Dadru,Tinea corporis.

\section{Introduction:}

Skin is the largest organ of human body. Its size and external location makes it susceptible to various disorders. In recent years, there has been a considerable increase in the incidence of skin problem in the tropical and developing countries like India. (1) All the skin diseases in Ayurveda have been classified under the broad heading of 'Kushta' which are further classified into Mahakushta and Kshudrakushta. Dadru is one amongst them. (2) Acharya Charak has included Dadru in Kshudrakushta,(3) whereas Acharya Sushruta and Acharya Vagbhata have explained under Mahakushta. (4), (5) Vishamashana (Incompatible food), vegavidharana (suppression of natural urges), diwaswapa (daytime sleeping), intake of atilavana, atitikshnaahar (excessive salty or spicy food), intake of contaminated food, drinking cold water just after physical work or atapsevana (exposure to sunlight) are causative factors of Kushta.(6) The main lakshanas of

* Corresponding Author:

\section{Manish Chavhan}

PG scholar, Department of Kayachikitsa,

Mahatma Gandhi Ayurveda College, Hospital,

Research Centre, Salod (H),

Wardha, Maharashtra.

Email id-manishchavhan10@gmail.com
Dadru include Kandu (Itching), Utsanna (elevated circular lesions), Mandala (Circular Patches), Raaga (Erythema), and Pidakas (Papule). The samprapti of Dadru mainly involves vitiation of Pitta-kapha doshas and dushti of rasa and raktavaha strotas. (7) Due to similarity of symptoms Dadru can be correlated with Tinea corporis, which is a fungal skin infection. The related fungi are dermatophytes capable of causing skin changes of the type known as Tinea or ringworm or dermatophytosis or Mycosis. (8) 5 out of 1000 people are suffering from Tinea infection. (9) In modern medical science, it is managed with topical and systemic antifungal agents and use of corticosteroids. In Ayurveda Shodhan, Shaman and Bahirparimarjan (topical) Chikitsa is indicated for Dadru. $(10,11)$ All these treatment modalities are used in this case study. For shodhana nitya virechana with Gomutra siddha haritaki was given. In Shamana chikitsa formulations like Arogavardhini vati and Gandhaka Rasayana having Kushtaghna, Krumighna and Kandughna properties were used. Bahiparimarjana chikitsa was given in the form of lepa of S-kin powder with gomutra and local application of Karanj oil.

\section{Case Report}

50 years old female came to Kayachikitsa OPD of Mahatma Gandhi Ayurveda College Hospital \& Research Centre, Salod (H) Wardha with Chief complaints of round and reddish patches over abdominal region with severe itching for 20 days. 
History of present illness

Patient was well before 20 days, and then she gradually developed the round and reddish patches over abdominal region with severe itching. For that she had taken Allopathic treatment from local practitioner but didn't get satisfactory result so, she came to MGAC Hospital for management.

\section{Past History}

There was no any past history of Diabetes mellitus, Hypertension, Asthma \& Hypothyroidism.

\section{Family History}

Husband had similar complaints.

\section{Clinical Examination}

Ashthavidh pariksha was within normal limit except patient had constipation. Patient had madhyam akruti.

Local examination - 4-5 circular erythematous, well demarcated patches with some vesicular eruption over abdominal area. No discharge from lesion. normal limit

Vital parameters- Vitals parameters were within

\section{Diagnosis}

From clinical features it was diagnosed as Dadru (Tinea corporis).

Table No 1: Treatment suggested

\begin{tabular}{|c|c|c|c|}
\hline $\begin{array}{l}\text { Sr. } \\
\text { no. }\end{array}$ & Drug given & Dose /Anupan & $\begin{array}{l}\text { Duration/ } \\
\text { Time }\end{array}$ \\
\hline 1 & $\begin{array}{l}\text { Arogyavardhini } \\
\text { vati }\end{array}$ & $\begin{array}{l}500 \mathrm{mg} \text { twice a } \\
\text { day with koshna } \\
\text { jala (lukewarm } \\
\text { water) }\end{array}$ & $\begin{array}{l}14 \mathrm{~d} \text { a y s / } \\
\text { after food }\end{array}$ \\
\hline 2 & $\begin{array}{l}\text { Gandhak } \\
\text { rasayan }\end{array}$ & $\begin{array}{l}500 \mathrm{mg} \text { twice a } \\
\text { day with koshna } \\
\text { jala (lukewarm } \\
\text { water) }\end{array}$ & $\begin{array}{l}14 \text { d a y s / } \\
\text { after food }\end{array}$ \\
\hline 3 & $\begin{array}{l}\text { Gomutra siddha } \\
\text { Haritaki }\end{array}$ & $\begin{array}{l}\text { 5gm at night with } \\
\text { kos } h \text { n } \text { jal } \\
\text { (lukewarm water) }\end{array}$ & $\begin{array}{l}14 \text { d a y s / } \\
\text { after food at } \\
\text { night }\end{array}$ \\
\hline 4 & S-kin powder & $\begin{array}{l}\text { Local application } \\
\text { with Gomutra }\end{array}$ & Before bath \\
\hline 5 & Karanja oil & Local application & Twice a day \\
\hline
\end{tabular}

Follow up- After 7 days

\section{Investigations}

$\mathrm{CBC}$ and RBS were within normal limits

\section{Assessment criteria}

Assessment of patient was done on the basis of improvement in subjective parameters like Kandu (Itching), Raaga (Erythema), Utsanna mandala (Elevated circular skin, Lesion) and Pidika (Eruption) and photographs of lesion before, during and after treatment.
Table No 2: Gradation of Parameters

\begin{tabular}{|c|c|c|c|c|}
\hline SN & $\begin{array}{l}\text { Grade } \\
0\end{array}$ & Grade 1 & Grade 2 & Grade 3 \\
\hline $\begin{array}{l}\text { Kandu } \\
\text { (Itching) }\end{array}$ & Absent & $\begin{array}{l}\text { Mild or } \\
\text { Occasion } \\
\text { al Itching }\end{array}$ & $\begin{array}{l}\text { Moderate } \\
\text { or } \\
\text { Frequent } \\
\text { Itching }\end{array}$ & $\begin{array}{l}\text { S e vere } \\
\text { Itching }\end{array}$ \\
\hline $\begin{array}{l}\text { Utsanna } \\
\text { mandala } \\
\text { (Elevated } \\
\text { circular } \\
\text { skin } \\
\text { lesion) }\end{array}$ & Absent & $\begin{array}{l}\text { M i l d } \\
\text { elevated } \\
\text { lesion }\end{array}$ & $\begin{array}{l}\text { Moderate } \\
\text { elevated } \\
\text { lesion }\end{array}$ & $\begin{array}{l}\text { Severe } \\
\text { elevated } \\
\text { lesion }\end{array}$ \\
\hline $\begin{array}{l}\text { Pidika } \\
\text { (Eruption) }\end{array}$ & Absent & $\begin{array}{lr}1 \quad & -3 \\
\text { eruptions }\end{array}$ & $\begin{array}{l}4 \quad-\quad 7 \\
\text { eruptions }\end{array}$ & $\begin{array}{lr}> & 7 \\
\text { eruptions }\end{array}$ \\
\hline $\begin{array}{l}\text { Raaga } \\
\text { (Erythema) }\end{array}$ & Absent & Present & & \\
\hline
\end{tabular}

\section{Observation and Results}

Table No 3: Assessment before, during and after treatment

\begin{tabular}{|c|c|c|c|}
\hline Symptoms & $\begin{array}{c}\text { On Day } \\
\text { 0 }\end{array}$ & $\begin{array}{c}\text { On } \\
\text { Day 7 }\end{array}$ & $\begin{array}{c}\text { On } \\
\text { Day 14 }\end{array}$ \\
\hline Kandu (Itching) & 3 & 2 & 0 \\
\hline $\begin{array}{c}\text { Utsanna mandala } \\
\text { (Elevated circular } \\
\text { skin lesion) }\end{array}$ & 3 & 1 & 0 \\
\hline Pidika (Eruptions) & 3 & 2 & 0 \\
\hline Raaga (Erythema) & 1 & 1 & 0 \\
\hline
\end{tabular}

Before treatment Gradation of Kandu was 3 (Severe Itching) which reduced to 2 (Moderate or Frequent Itching) during first follow up and it was absent on day 14 that is after completion of treatment. Before treatment Gradation of Utsanna mandala was 3 (Severe elevated lesion) which reduced to 1 (Mild elevated lesion) during first follow up and it was absent on day 14 that is after completion of treatment.

Before treatment Gradation of Pidika was 3 (> 7 eruptions) which reduced to 2 (4-7 eruptions) during first follow up and it was absent on day 14 that is after completion of treatment

Before treatment Raaga (Erythema) was present that persists during first follow up and it was absent on day 14 that is after completion of treatment.

Thus complete improvement was observed in all parameters after completion of treatment. Same can be seen in following pictures taken before, during and after treatment.

\section{Before Treatment: Figure-1- On day 0}
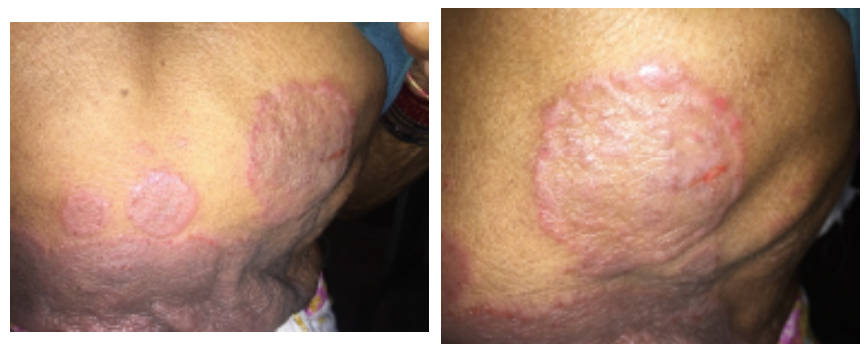
First follow up : Figure-2- On day 7
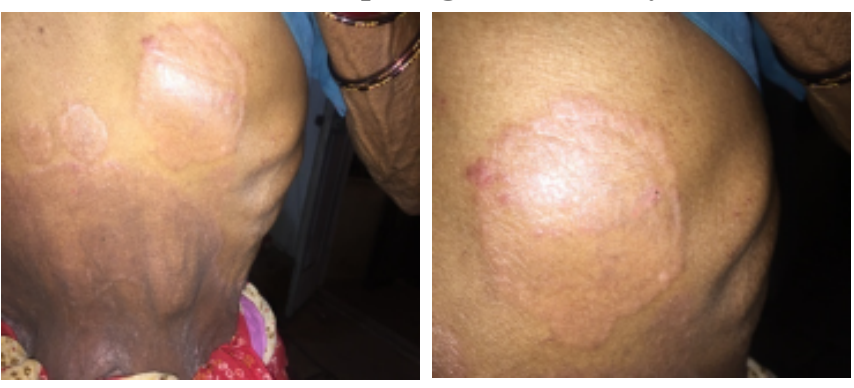

Second follow up : Figure-3- On day 14
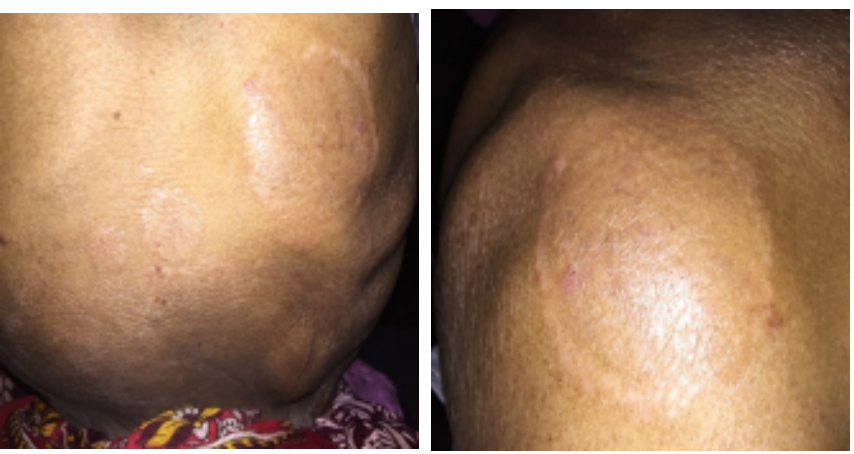

\section{Discussion}

All Kushta are Tridoshaj. But according to Acharya Charak and Vagbhata, Dadru is Pitta-Kapha dominance and according to Acharya Sushruta it is Kaphapradhan. There is involvement of Rasa and Rakta in the samprapti. In Samhita repeated Shodhana and Shamana drugs having Kushtaghna, Krumighna and Kandughna properties are described for Kushta. Along with this, for better result, Bahiparimarjana Chikitsa (local application of drugs) in the form of lepa and oil was also advised. In this case study the patient was treated with internally Gomutra siddha Haritaki Churna, Arogyavardhini vati and Gandhaka rasayana with external application of S-kin powder lepa with Gomutra and karanja oil for 14 days.

\section{Probable mode of action of Arogyavardhini vati}

Arogyavardhini vati is a herbomineral formulation mainly indicated in Kushta roga. The main ingredient of Arogyavardhini vati is Kutaki (Picrorrhiza kurroa Royle ex Benth). It also contains Haritaki (Terminalia chebula Retz.), Bibhitaka (Terminalia bellerica (Gaertn.) Roxb.), Amalaki (Emblica officinalis Gaertn), Shilajatu Shuddha (Asphaltum), Guggulu Shuddha (Commiphora wightii Arn.), Eranda (Ricinus communis Linn.), and minerals like Shuddha Parada (purified mercury), Shuddha Gandhaka (purified sulfur), Lauha Bhasma (iron compound in ash form), Abhraka Bhasma (mica in ash form), and Tamra Bhasma (copper compounds in ash form) with bhavana of nimba (Azadirachta indica A.Juss) patra swarasa. Due to all these ingredients it possesses pitta virechan, tridosha shamak, deepan, pachan, kushthaghna, and kandughna properties. Due to these properties it helps in balancing tridosha, causes agnivardhana, bhedana, malashodhana and vatanulomana. (12) Kushtaghna and Kandughna properties help in relieving symptoms and breaking samprapti of disease.

\section{Probable mode of action of Gandhak rasayan}

Gandhak rasayan is a polyherbal drug prepared by giving 12 bhavanas of herbal drugs to Shuddha Gandhaka. It is mainly indicated in the management of Kushta Roga. (13) It possesses antibacterial and antifungal properties. It mainly acts on Rakta Dhatu and causes Rakta shodhan (purification of blood). It helps in reducing infection by its antifungal property. It also acts as Rasayana and helps in improving the digestion and skin complexion. Sulfur is used both internally and externally for treatment of diseases of skin. It reduces the Kandu, Pidika, Raaga and Daha by its Rakta shodhak, Vranaropak, Krumighna and Kushthaghna properties. (14)

\section{Probable mode of action of Gomutra-siddha haritaki}

Repeated shodhana is indicated in Kushta by all Acharyas. Haritaki has mrudu virechak property. Dadru is kapha-pitta pradhana vyadhi. So, Gomutra siddha haritaki is used for nitya Virechan which help in elimination of vitiated doshas. Bhavana of Gomutra enhances its potency and also helps in virechana.(15)

\section{Probable mode of action of Karanja oil}

According to Ayurveda, Karanj is anthelmintic, alexipharmic and useful in diseases of eye, vagina, skin. It is good for tumour, wounds, ulcers, itching, ascites, enlargement of spleen and abdomen, urinary discharges. It also cures biliousness, piles, head pains, leucoderma, skin diseases and wounds. According to Unani system of medicine,seeds are acrid and carminative, purify and enrich blood, relieves inflammations, cure earache, chest complaints, lumbago, chronic fever and hydrocele.

Karanj oil is described in Bhaishajya Ratnavali in Visarpa Chikitsa. Its main ingredients are Karanja (Pongamia pinnata (Linn) Merr.), Saptachada (Alsonia scholaris R.Br.), Langli (Gloriosa superb Linn.), Snuhi (Euphorbia nerifolia Linn.), Arka (Calatropis procera R.Br.), Anala (Plumbago zeylanica Linn.), Bhrigaraja (Eclipta alba Linn.), Nisha (Curcuma longa Linn), Gomutra (Cow urine), Visha (Aconitum ferox Wall. ex Ser.) in Murcchita sesame oil.(16) It has Krumighna (antifungal, antibacterial activity), Kandughna, Vranaropaka and Vranashodhaka properties.(17) These properties help in reducing symptoms. Local application is useful for fast absorption and also reduces roughness.

\section{Probable mode of action of S-kin Powder}

S-kin Powder contains fine powder of Manjistha (Rubia cordifolia Linn.), Amalaki (Emblica officinalis Gaertn),, Haridra (Curcuma longa Linn.), Bibhitaka (Terminalia bellerica (Gaertn.) Roxb.), Nagarmotha (Cyperus rotundus R.Br. ) and Shudha Gandhaka (Purified Sulphur). All these drugs have Krumighna (antibacterial, antimicrobial, and antifungal), Raktashodhak (blood purifying) and Vranaropak (wound healing) properties. It is applied with Gomutra which enhances the absorption. Shodhit Gandhak is useful in the management of all types of skin disorders. Hence topical application of it helps in 
reducing symptoms of Dadru like Kandu, Raaga, Utsanna mandala and Pidikas.

\section{Conclusion}

Dadru kushta is a type of Kshudrakushta according to Acharya Charak \& Mahakushtha according to Acharya Sushruta and Acharya Vagbhata. It can be correlated with Tinea corporis or dermatophytosis. As it is a contagious disease, personal hygiene is an important part in its management. From this case study it can be concluded that use of Chikitsa upakramas described in Ayurveda like Shodhana (Nitya virechana with Gomutra siddha haritaki), Shamana (formulations like Arogyavardhini vati, Gandhak rasayan) and Bahiparimarjana (lepa of S-kin powder in gomutra and local application of Karanj oil) are effective in the management of Dudru kushta.

\section{References}

1. Ronald Marks, Roxburgh's Common Skin Diseases, 16th Edition, ELBS with Chapman \& Hall, London, Chapter-1, 1993:1.

2. Sharma PV, Charaka Samhita of Agnivesha with English Translation, 1st Edition-Reprint, Chaukhambha Orientalia,Varanasi. Vol-2, 2008:183.

3. Sharma PV, Charaka Samhita of Agnivesa with English Translation,1st Edition-Reprint, Chaukhambha Orientalia,Varanasi, vol-2,2008:184

4. Jadavaji Trikamji, Choukambha Orientalia, Sushruta Samhita (Commentary of Dalhanacharya) and the Nyaya Chandrika, Varanasi. 5th edition; 2005:37

5. Desai Ranajitaraya, AshtangaSangraha of Sarvanga Sundari Vyakhyaya Samhita Sutrasthana- Prathama Bhaga, Shri. Baidyanath Ayurveda Bhavana, pvt. Ltd Nagpur, 3rd edition; 1986:137

6. Tripathi Ravidatta and Shukla Vidyadhar 'Charaksamhita' Vol. 2 - Chikitsasthana 'Kushtha chikitsitam Adhyaya' 7/4-8 - Edition Chaukhamba Sanskrit Pratisthan, Delhi, 2013; 181
7. Shukla Vidyadhar and Ravi Dutt Tripathi Charak Samhita of Agnivesha revised by Charaka Redacted By Drudbala with vaidya manorama' hindi commentary, Chaukambha Sanskrit pratishthan, Delhi reprint-2011 chapter- 7 chikitsasthanshloka29-30 pp.185

8. Burns, Breathnach, Cox, Griffiths, Rook's textbook of dermatology, Blackwell publishers, 7th edition2004, vol- 2, chpter-31.19

9. Sharma Usha, Tinea infections, unwanted guests; 2010[Express Pharma]; p.1.

10. Jadavaji Trikamji Agnivesha, Charaka, Dridhabala, Charaka Samhita, Sutra Sthana. In: 1st ed., 16/20. Varanasi: Krishnadas Acadamy; 2000. p. 97.

11. Kushwaha Harish Chandra Singh, Charaka Samhita, Ayurveda Dipika Ayushi, Hindi commentary edited by Vd. Vol-II 7/41, Varanasi: Chaukhamba Orientalia; 2009. p.209

12. Mishra Siddhinandan 'Bhaishajya Ratnavali by Kaviraj Govind Das Sen' - Kushtharogadhikara 54/111-117 Edition Chaukhamba Subharati Prakashana Publication, Varanasi, 2016; p. 871.

13. Gune Gangadhar shastri - 'Aayurvediya Aushadhigunadharmashastra'- Part 2 - 30 Vaidyak Granth Bhandar Publication, 2011; p.271.

14. Saokar R et al, Screening of Antibacterial and Antifungal Activity of Gandhaka Rasayana- an Ayurvedic Formulation, International Journal of Recent Trends in Science And Technology, 2013, Vol. 8( 2), pp 134-137

15. Tripathi Indradeva, Gadanigraha Choukambha Kayachikitsa khanda Kustharogadhikar pp. 788.

16. Mishra Bramhashankar, Bhaishajya Ratnavali, VolIII edition 1st, 57/26, New Delhi: Chaukhamba Sanskrit Bhavan; 2006.p.145

17. Rajput Satyendra singh H, et al, Use of Karanj Oil (Pongamia glabra) In Topical Formulation. Research Journal of Pharmaceutical, Biological and Chemical Sciences · Jan. 2014, 5(3), pp. 546. 